\title{
Pentingnya Pendokumentasian Dalam Diagnosa Keperawatan
}

\author{
Syifa Amalia Br Gintng
}

Syifasamsung42@gmail.com

\section{Latar Belakang}

Keperawatan di Indonesia saat ini masih dalam suatu proses profesionalisasi, yaitu terjadinya suatu perubahan dan perkembangan karakteristik sesuai tuntutan secara global dan lokal. Untuk mewujudkannya maka perawat harus mampu memberikan asuhan keperawatan secara profesional kepada klien. Salah satu bukti asuhan keperawatan yang profesional tercermin dalam pendokumentasian proses keperawatan. Dokumentasi keperawatan adalah bagian dari keseluruhan tanggung jawab perawatan pasien. Catatan klinis memfasilitasi pemberian perawatan, meningkatkan kontinuitas perawatan dan membantu mengkoordinasikan pengobatan dan evaluasi pasien.

Dokumentasi keperawatan sangat penting bagi perawat dalam memberikan asuhan keperawatan karena pelayanan keperawatan yang diberikan kepada klien membutuhkan catatan dan pelaporan yang dapat digunakan sebagai tanggung jawab dan tanggung gugat dari berbagai kemungkinan masalah yang dialami klien baik masalah kepuasan maupun ketidakpuasan terhadap pelayanan yang diberikan. Dokumentasi keperawatan merupakan suatu yang mutlak harus ada untuk perkembangan keperawatan khususnya proses profesionalisasi keperawatan serta mempertahankan keperawatan sebagai suatu profesi yang luhur dan terpandang di masyarakat. Dokumentasi keperawatan dalam bentuk dokumen asuhan keperawatan merupakan salah satu alat pembuktian atas tindakan perawat selama menjalankan tugas pelayanan keperawatan.

Sering sekali perawat kesulitan dalam menentukan diagnosis keperawatan spesifik yang dialami oleh pasien. Hal ini mungkin karena pengkajian keperawatan yang tidak terstrukturdengan baik. Pengkajian yang dilakukan oleh perawat tidak mempunyai urutan yang runut dan terkait dengan diagnosis keperawatan. Sering terjadi bahwa perawat mempunyai data tertentu tetapi kebingungan untuk menentukan data tersebut mendukung diagnosis keperawatan yang mana. Atau sebaliknya perawat mempunyai prediksi pasien mempunyai diagnosis tertentu tetapi tidak tahu data apa yang perlu dikaji untuk mendukung diagnosis tersebut muncul 


\section{Metode}

Metoode penelitian yang digunakan yaitu dengan cara menganalisis artikel, , jurnal maupun text book, yang diterbitkan sepuluh tahun terakhir yang menggunakan google scholar,google book dan science direct., Dalam mencari artikel, kata kunci yang digunakan ialah hal yang harus diperhatikan dalam melakukan pendokumentasian asuhan keperawatan Di Rumah Sakit.

\section{Hasil}

Pelayanan keperawatan atau sering disebut Asuhan keperawatan merupakan proses atau rangkaian kegiatan praktik keperawatan langsung pada klien di berbagai tatanan pelayanan kesehatan yang pelaksanaannya berdasarkan kaidah profesi keperawatan dan merupakan inti praktik keperawatan. Di dalam asuhan keperawatan mutu asuhankeperawatan sangat dipengaruhi oleh kualitas pelayanan kesehatan dan bahkan sering menjadi salah satu faktor penentu citra institusi palayanan di mata masyarakat.

Ketepatan melakukan diagnosa menjadi langkah awal dalam sebuah proses pengobatan karena ketepatan dalam melakukan diagnosa maka akan mempengaruhi tindakan yang akan dilakukan selanjutnya. Diagnosa juga meliputi penentuan kebutuhan pasien untuk perawatan seperti dukungan, bimbingan, jaminan, pendidikan, pelatihan, dan perawatan lainnya yang memfasilitasi kemampuan pasien untuk mencari perawatan.

Proses mengkaji dan mendiagnosis merupakan kegiatan yang sangat penting karena menentukan keberhasilan asuhan keperawatan. Dalam merumuskan diagnosis keperawatan terdapat beberapa kegiatan yang dilakukan dalam mendiagnosis keperawatan yaitu interpretasi dari data yang ada, kemudian melakukan verifikasi dengan pasien, menentukan label diagnosis keperawatan dan menuliskan diagnosis keperawatan.Pada saat perumusan diagnosa keperawatan membutuhkan proses berpikir kritis,keterampilan penalaran dan pengalaman sebelumnya

Perawat harus sebagai 'Penegak Diagnosis' keperawatan yangsudah terstandar dan ditetapkan oleh organisasi profesi PPNI dan disahkan oleh menteri, yaitu Standar Diagnosis Keperawatan Indonesia (SDKI).Hal yang dimaksud dengan standar profesi adalah batasan kemampuan (capacity) meliputi pengetahuan (knowledge), keterampilan (skill), dan sikap professional (professional attitude) yang minimal harus dikuasai oleh seorang individu untuk dapat melakukan kegiatan profesionalnya pada masyarakat secara mandiri yang dibuat oleh organisasi profesi. 


\section{Pembahasan}

Diagnosa keperawatan merupakan suatu penilaian klinis mengenai respons klien terhadap masalah kesehatan atau proses kehidupan yang dialaminya baik yang berlangsung aktual maupun potensial. Diagnosis keperawatan bertujuan untuk mengidentifikasi respons klien individu,keluarga, komunitas terhadap situasi yang berkaitan dengan kesehatan.

Perawat diharapkan memiliki rentang perhatian yang luas, baik pada klien sakit maupun sehat. Respons-respons tersebut merupakan reaksi terhadap masalah kesehatan dan proses kehidupan yang dialami klien. Masalah-masalah mengacu kepada proses respons klien terhdap kondisi sehat-sakit, sedangkan proses kehidupan mengacu pada respons klien terhadap kondisi yang terjadi selama rentang kehidupannya dimulai dari fase pembuahan hingga menjelang ajal dan meninggal yang mebutuhkan diagnosa keperawatan dan dapat diatasi atau diubah dengan intervensi keperawatan

Setiap pelaksanaan proses keperawatan, perawat akan selalu melakukan pencatatan atau sering disebut pendokumentasian, mulai dari pengkajian, diagnosis, perencanaan, pelaksanaan dan evaluasi. Dokumentasi merupakan aspek penting dari praktik keperawatan karena berisi catatan-catatan yang berguna untuk komunikasi,tagihan finansial, edukasi, pengkajian, riset, audit dan dokumentasi legal (Potter \& Perry, 2005 dalam Wirawan, Emanuel Agung). Hakikat dokumentasi asuhan keperawatan adalah terciptanya kegiatan-kegiatan keperawatan yang menjamin tumbuhnya pandangan, sikap, cara berpikir, dan bertindak profesionalpada setiap perawat

Diagnosa keperawatan adalah langkah kedua dari proses keperawatan yang menggambarkan penilaian klinis tentang respon individu, keluarga, kelompok maupun masyarakat terhadap permasalahan kesehatan baik aktual maupun potensial. Dimana perawat mempunyai lisensi dan kompetensi untuk mengtasinya

Manfaat Dokumentasi Keperawatan

Dokumentasi mempunyai makna yang penting bisa dilihat dari berbagai aspek, antara lain :

1. Hukum, semua catatan informasi tentang klien merupakan dokumentasi resmi dan bernilai hukum. Nah, jika terjadi suatu masalah yang berhubungan dengan profesi keperawatan, dimana perawat sebagai pemberi jasa dan klien sebagai pengguna jasa, oleh karena itu 
dokumentasi dapat digunakan sewaktu-waktu.

Karena dokumentasi tersebut nantinya dapat dipergunakan sebagai barang bukti di pengadilan. Maka dari itu, semua data-data yang diidentifikasi harus benar-benar lengkap, jelas, objektif dan juga ditanda tangani oleh tenaga kesehatan (perawat), tanggal serta hindari adanya penulisan yang dapat menimbulkan kesalahan interpretasi.

2. Kualitas pelayanan, pada kualitas pelayanan perawat akan mudah dalam menyelesaikan masalah si klien, apabila pendokumentasian data klien lengkap dan akurat dengan begitu perawat akan dengan mudah menyelesaikan masalah klien tersebut.

Selain itu, untuk mengetahui sejauh mana masalah tersebut dapat diatasi dan dimonitor melalui dokumentasi data yang akurat dan lengkap tersebut. dengan begitu akan meningkatkan kualitas (mutu) pelayanan keperawatan

3. Komunikasi, dokumentasi dapat dikatakan juga sebagai alat perekam terhadap masalah terkait si klien. Dengan adanya dokumentasi tersebut dapat menjadi alat komunikasi untuk si perawat atau tim kesehatan lainnya agar dijadikan pedoman dalam memberlakukan asuhan keperawatan

4. Keuangan, sebagai acuan atau pertimbangan dalam biaya perawatan terhadap klien

5. Pendidikan, sebagai bahan atau referensi pembelajaran

6. Penelitian, dalam dokumentasi memiliki nilai penelitian. Nah, data tersebut mengandung informasi yang bisa dijadikan sebagai bahan atau objek riset pengemangan profesi keperawatan

7. Akreditasi, dengan melalui dokumentasi keperawatan akan dapat dilihat sejauh mana peran dan fungsi perawat dalam memberikan asuhan keperwatan klien. Hal ini akan bermanfaat bagi rpeningkatan mutu pelayanan dan bahan pertimbangan dalam kenaikan jenjang karir atau kenaikan pangkat

\section{Prioritas Diagnosa Keperawatan.}

Menyusun prioritas sebuah diagnosa keperawatan hendaknya diurutkan sesuai dengan keadaan dan kebutuhan utama klien, dengan kategori:

1) Berdasarkan tingkat Kegawatan

a) Keadaan yang mengancam kehidupan

b) Keadaan yang tidak gawat dan tidak mengancam kehidupan.

c) Persepsi tentang kesehatan dan keperawatan.

2) Berdasarkan Kebutuhan maslow,yaitu Kebutuhan fisiologis,kebutuhan keamanan dan keselamatan,kebutuhan mencintai dan dicintai,kebutuhan harga diri dan kebutuhan aktualisasi diri. 


\section{Kategori Diagnosa Keperawatan}

Diagnosa Keperawatan Aktual

Diagnosa keperawatan aktual menurut NANDA adalah diagnosa yang menyajikan keadaan klinis yang telah divalidasikan melalui batasan karakteristik mayor yang diidentifikasi. Diagnosa keperawatan mempunyai empat komponen : label, definisi, batasan karakteristik, dan faktor yang berhubungan.

Label merupakan deskripsi tentang definisi diagnosis dan batasan karakteristik. Definisi menekankan pada kejelasan, arti yang tepat untuk diagnosa. Batasan karakteristik adalah karakteristik yang mengacu pada petunjuk klinis, tanda subjektif dan objektif. Batasan ini juga mengacu pada gejala yang ada dalam kelompok dan mengacu pada diagnosis keperawatan, yang teridiri dari batasan mayor dan minor. Faktor yang berhubungan merupakan etiologi atau faktor penunjang. Faktor ini dapat mempengaruhi perubahan status kesehatan. Faktor yang berhubungan terdiri dari empat komponen : patofisiologi, tindakan yang berhubungan, situasional, dan maturasional. Penulisan rumusan diagnosis ini adalah : PES (problem + etiologi + simtom).

Diagnosa Keperawatan Risiko atau Risiko Tinggi

Menurut NANDA, diagnosa keperawatan risiko adalah keputusan klinis tentang individu, keluarga atau komunitas yang sangat rentan untuk mengalami masalah dibanding individu atau kelompok lain pada situasi yang sama atau hampir sama.

Diagnosa keperawatan ini mengganti istilah keperawatan potensial dengan menggunakan "risiko terhadap atau risiko tinggi terhadap". Validasi untuk menunjang diagnosis resiko tinggi adalah faktor resiko yang memperlihatkan keadaan dimana kerentanan meningkat terhadap klien atau kelompok dan tidak menggunakan batasan karakteristik. Penulisan rumusan diagnosis ini adalah : PE (problem \& etiologi).

\section{Diagnosa Keperawatan Kemungkinan}

Menurut NANDA, diagnosa keperawatan kemungkinan adalah pernyataan tentang masalah yang diduga masih memerlukan data tambahan dengan harapan masih diperlukan untuk memastikan adanya tanda dan gejala utama adanya faktor resiko.

\section{Diagnosa Keperawatan Sejahtera}

Menurut NANDA, diagnosa keperawatan sejahtera adalah ketentuan klinis mengenai individu, kelompok, atau masyarakat dalam transisi dari tingkat kesehatan khusus ke tingkat kesehatan yang lebih baik. Cara pembuatan diagnosa ini adalah dengan menggabungkan pernyataan fungsi positif dalam masing-masing pola kesehatan fungsional sebagai alat 
Simamora, R. H., Bukit, E., Purba, J. M., \& Siahaan, J. (2017). Penguatan kinerja perawat dalam pemberian asuhan keperawatan melalui pelatihan ronde keperawatan di rumah sakit royal prima medan. Jurnal pengabdian kepada masyarakat, 23(2), 300-304.

pengkajian yang disahkan. Dalam menentukan diagnosa keperawatan sejahtera, menun jukkan terjadinya peningkatan fungsi kesehatan menjadi fungsi yang positif.

\section{Penutupan}

Karena pentingnya pengkajian maka untuk itu perawat harus bisa mengkaji pasien dengan baik dan benar dan dapat terampil. Agar tidak terjadi kesalahan-kesalahan yang tidak diinginkan. Karena melalui pengkajian perawat mendapat informasi yang dapat di gunakan menjadi penelitian.

\section{Daftar Pustaka}

Astuti, Neneng, Yeni Yarnita, and Eva Mayasari. "Analisis Kelengkapan Pendokumentasian Asuhan Keperawatan Pasien di Ruang Rawat Inap Rumah Sakit Tampan Pekanbaru." Photon: Jurnal Sain dan Kesehatan 1.1 (2012): 17-21.

Husnah, Rizky Asmaul. "PENTINGNYA DIAGNOSA KEPERAWATAN UNTUK PASIEN DAN PERAWAT." (2019).

Marina, Monika Naulia. "PENTINGNYA MENGETAHUI DIAGNOSA KEPERAWATAN DENGAN BAIK DAN BENAR." (2019).

Nubuwah, Resky Titha Nurun. "PENTINGNYA DIAGNOSA KEPERAWATAN YANG TEPAT UNTUK PEMBERIAN ASUHAN KEPERAWATAN YANG TEPAT." (2019).

Putra, Ageng Abdi, Sri Rejeki, and Tri Nur Kristina. "Hubungan persepsi perawat tentang karakteristik pekerjaan dengan kepatuhan dalam pendokumentasian asuhan keperawatan." Jurnal Keperawatan Notokusumo 4.1 (2016): 1-11.

Sinaga, Bintang Pangestu. "PENTINGNYA PERAN DAN TUGAS SEORANG PERAWAT DALAM PENGKAJIAN PADA PASIEN." (2019).

Simamora, R. H. (2019). Socialization of Information Technology Utilization and Knowledge of Information System Effectiveness at Hospital Nurses in Medan, North Sumatra. Editorial Preface From the Desk of Managing Editor..., 10(9).

Siswanto, LM Harmain, Rr Tutik Sri Hariyati, and Sukihananto Sukihananto. "Faktor-Faktor yang berhubungan dengan kelengkapan pendokumentasian asuhan keperawatan." Jurnal Keperawatan Indonesia 16.2 (2013): 77-84.

Supratti, Supratti, and Ashriady Ashriady. "Pendokumentasian Standar Asuhan Keperawatan Di Rumah Sakit Umum Daerah Mamuju." Jurnal Kesehatan Manarang 2.1 (2018): 44-51.

Tari, Cut. "Pentingnya Melakukan Diagnosa Keperawatan Bagi Perawat di Rumah Sakit." (2019). 